ціон льний університет водного господ рств $m$ природокористув ння, вул. оборн , 11, м. івне, 33000, кр їн ,e-mail:ak74d@ukrwest.net

ро н лізов но т висвітлено концепту льні підходи стосовно методів економічної оцінки мінер льно-сировинних ресурсів н др конкретних територій. Зв но шляхи вр хув ння невизн ченості поч ткової інформ ції про н явні т імовірні з п си родовищ корисних коп лин, пов'яз ні зі ступенем достовірності геологічних д них.

лючові слов : мінер льні ресурси, корисні коп лини, оцінк , рент .

явність н території кр їни різном нітних геологічних структур і великого фонду родовищ корисних коп лин сприяли розвитку мінер льно-сировинного комплексу. кр їн н лежить до регіонів світу з високим рівнем геологічної вивченості території, н сиченості мінер льними ресурс ми т зн чними обсяг ми їх з лучення в господ рський обіг. Сьогодні в її н др х н лічується близько 20000 родовищ і проявів 116 видів корисних коп лин природного т техногенного походження. ромислове зн чення м ють 97 видів корисних коп лин, які вр хов ні ерж вним 6 л нсом з п сів. кр їн видобув є близько 5 \% світового обсягу мінер льної сировини, тоді як територія н шої держ ви ст новить лише $0,4 \%$ світової. г тство природних ресурсів, н с мперед мінер льно-сировинних, - основ економічного зрост ння держ ви 3 умови їх розумного використ ння [1].

ля післякризового періоду в кр їні х р ктерне зрост ння промислового виробництв , передусім, з вдяки гірничодобувній промисловості. цих умов х, природно, держ в потребує грунтовного підходу до визн чення доступності родовищ корисних коп лин. сновною метою економічної оцінки родовищ корисних коп лин є визн чення можливості з лучення з п сів у розробку з н явного технічного рівня розвитку суспільств , з ур хув нням його потреб у певних вид х мінер льних ресурсів [2].

цінк об'єднує в собі результ ти геологічної, геогр фічної, технологічної т промислової х р ктеристик родовищ корисних коп лин. езульт том геологічної оцінки $є$ інформ ція про з п си корисних коп лин, речовинний скл д тощо. ході технічного і технологічного оцінюв нь вибир ють спосіб розкриття, системи розробки, схеми зб г чення мінер льної сировини.

еогр фічн скл дов оцінки поляг є у вр хув нні конкретних територі льних умов розміщення родовищ мінер льної сировини з огляду н визн чені геологічні, клім тичні т територі льні умови.

тупінь прид тності з п сів корисних коп лин для експлу т ції визн ч ють промисловою оцінкою родовищ. цьому вип дку оцінюють потребу в конкретному виді сировини, ступінь і джерел іiї з доволення; можливість родовищ з кількістю і якістю

(C) лько ., 2011 
3 п сів, гірничо-геологічними умов ми 3 ляг ння і геогр фічним положенням бути об'єктом для будівництв гірничого підприємств ; розмір к піт льних вкл день, очікув н собів ртість 1 т сировини. кономічну оцінку роблять для родовищ, які одерж ли позитивну промислову оцінку [3, 4].

тже, не вип дково пит ння економічної оцінки мінер льно-сировинних ресурсів відобр жені в пр цях вітчизняних т з рубіжних ф хівців різних г лузей: геологів, геогр фів, гірників, економістів і проектув льників, зокрем . рушков [5], . рейтеp , . ервушин , . вленк , . чковського, . ож рицького [6], . олодомонов , к деміків . гошков [7], . ч туров [8] т . омер нцев [9], професорів . ст хов , . цК [2], . еж нової [10], . озловського [11], . весик [12], . іщенк [13], . ренк , . удьк [1], . урського [14], . ошовського $[11,14]$ т ін.

кщо методології викон ння геологічної і технологічної оцінок родовищ корисних коп лин грунтув лися н сукупності зн нь у г лузі проведення геологорозвідув льних робіт, методів оконтурюв ння, підр хунку з п сів, вибору способів розробки і переробки мінер льних ресурсів і з г лом не виклик ли розбіжностей, то ст новлення методології економічної оцінки родовищ відбув лося скл дно [12].

умов х соці лістичного устрою вв ж ли неприйнятним використ ння поширених у к піт лістичному суспільстві критеріїв економічної оцінки мінер льно-сировинних ресурсів.

1931 р. . рушков з пропонув в оцінюв ти суспільну в ртість родовищ у вигляді прибутку бо доходу, очікув них від експлу т ції родовищ [5]. нший погляд [6] поляг в у необхідності вр хув ння під ч с оцінюв ння родовищ в ртісних і н тур льних пок зників, які відобр ж ють потребу господ рств в корисній коп лині; обсяги не тільки чистого продукту, всієї продукції; б л нс розвід них з п сів; можливість внесення к піт льних витр т і з вд ння господ рського будівництв .

отрібно було розробити принципово новий підхід, який би вр ховув в не тільки прямі, видимі вигоди, й вторинний ефект від освоєння мінер льно-сировинних ресурсів, т кож перспективи розвитку продуктивних сил у господ рстві [7].

1955 р. к деміки . бручов, . кочинський, А. ерпігорєв т інші ініціюв ли поч ток створення методології грошової оцінки родовищ корисних коп лин. ї мет передб ч л порівняння економічних результ тів геологорозвідув льних робіт з грошовими витр т ми н них, оцінку н йбільш вигідного способу, темпу і порядку розробки, удоскон лення методики розвідки і підр хунку з п сів.

огляду н це, . ож рицький з пропонув в спосіб економічної оцінки родовищ корисних коп лин через дисконтов ний прибуток бо диференційну гірничу ренту [6], що було модифік цією формули X. осколд , 3 пропонов ної для оцінки гірничих проектів ще 1877 p. рошову цінність родовищ $\mathrm{x}$ р ктеризув ли ефектом від розробки родовищ :

$$
V_{p}=\sum_{i=1}^{n} \frac{A_{i}}{(1+r)^{i}},
$$

де: $A_{i}-$ чистий дохід від експлу т ції коп льні в $i$-му році; $r$ - обліков ст вк, \%; $n$ - трив лість експлу т ції, роки.

е ст ли успішними спроби створити принципово новий підхід до оцінки мінер льних ресурсів. езв ж ючи н різном ніття висловлених пропозицій, концепту льно різні думки щодо економічної оцінки мінер льно-сировинних ресурсів зводилися до ви- 
корист ння н родногоспод рської цінності ресурсів як одиниці вимірюв ння суспільно необхідних витр т н їхнє освоєння бо утворену диференційну ренту.

ерший підхід н з с д х теорії трудової в ртості . pкс відстоюв в к демік

трумілін. ідповідно до “витр тної” концепції, в ртість природного ресурсу повинн бути визн чен кількістю суспільно необхідної пр ці, витр ченої н його освоєння і підготовку до експлу т ції. одо мінер льно-сировинних ресурсів, то ці витр ти дорівнюють витр т м н геологорозвідув льні роботи. ід т кого підходу відмовилися через те, що оцінк родовищ корисних коп лин м л суперечливі результ ти порівняння родовищ з різними умов ми розробки, зумовленими природними чинник ми.

ільшість ф хівців у г лузі оцінки мінер льно-сировинних ресурсів сходилися н думці, що тільки диференційн рент може відобр зити суттєві відмінності природних умов освоєння родовищ. голошув ли, що хоч в умов х соці лізму земля і н др є об'єктом держ вної вл сності, вони є об'єктом господ рюв ння підприємств. е ліз ція ж держ вної вл сності н землю і її н др відбув ється шляхом вилучення держ вою рентного доходу.

рихильник “рентного” підходу к демік . ч туров ув ж в, що ефект від використ ння природного ресурсу вищої якості порівнянний з ефектом використ ння більш суч сних з собів пр ці [8]. p ничну величину к піт льних вкл день у з соби пр ці для отрим ння від них відповідного ефекту визн ч ли з допомогою норм тиву ефективності. уло з пропонов но оцінюв ти мінер льно-сировинні ресурси з вир зу

$$
S=\frac{R}{E_{H}},
$$

де $S$ - оцінк ресурсу; $R$ - середньорічн диференційн рент ; ${ }_{4}-$ норм тив ефективності; $t$ - роки з поч ткового моменту до року розр хунку ренти.

д лі було визн но, що користув тися формулою “к піт лізов ної” середньорічної гірничої ренти (2) можн тільки для оцінки родовищ корисних коп лин з трив лими термін ми відпр цюв ння, оскільки вон не вр ховує обмеженості мінер льних ресурсів.

о поч тку 80-х років пр ктично з г льновизн ною ст л “рентн” концепція економічної оцінки мінер льно-сировинних ресурсів, 3 основу якої взято дод тковий прибуток (н длишок н д середнім прибутком), одерж ний з ліпших природних умов виробництв .

имч совою типовою методикою економічної оцінки родовищ корисних коп лин [15] було рекомендов но оцінюв ти цінність родовищ 3 критерієм сум рного дисконту диференційної ренти:

$$
R_{p}=\sum_{t=1}^{T} \frac{Z_{t}-S_{t}}{\left(1+E_{H, n}\right)^{t}},
$$

де $R_{p}$ - грошов оцінк родовищ ; $Z_{t}$ - цінність річної продукції (з попутно вилученими компонент ми), обчислен в оптових цін х бо “з мик льних" витр т х $t$-го року; $S_{t}$ - сум м йбутніх к піт льних і експлу т ційних (без відр хув нь н мортиз цію в ч стині ренов ції) витр т в $t$-му році; н.п - норм тив для зведення різноч сних витр т і результ тів; - розр хунковий період оцінки родовищ (його ч стини), обчислений з року, щодо якого виконують оцінку до року відпр цюв ння з п сів.

роте і після з твердження етодики... деб ти н вколо методології грошової оцінки цінності родовищ не припинялися. 
озбіжності серед прихильників “рентної” концепції поляг ли, головно, у тр ктув нні “з мик льних” витр т і способ х ур хув ння чинник ч су. етодикою... [15] “з мик ючі витр ти х р ктеризують гр нично допустимий для певного періоду рівень питомих витр т н приріст виробництв д ного виду продукції гірничодобувних г лузей”. івень “з мик льних" витр т повинен з безпечув ти мінімум витр т у виробників і м ксимум ефекту у спожив чів природних ресурсів. йч стіше в цьому р зі використовув ли метод р нжув ння родовищ з розміром питомих зведених витр т н отрим ння кінцевої продукції, відповідно до якого з мик льні витр ти були витр т ми зони 3 мик ння з 10-15\% “пригр ничних" з п сів.

перечення виклик ло використ ння для поточного пл нув ння з мик льних витр т рівня приросту, який визн ч ли з перспективними пл н ми розвитку г лузі. е призводило до з вищення з мик льних витр т і оцінки природних ресурсів. ому пропонув ли визн ч ти дв рівні з мик льних витр т: діючий, який визн ч ють 3 "гіршою" ч стиною експлу тов них природних ресурсів конкретного виду, що слугує для економічної оцінки природних ресурсів з поточного пл нув ння, і госпрозр хунковою пр ктикою ре ліз ції пл нових рішень.

ей мех нізм дисконтув ння рентного доходу був розкритиков ний керівництвом геологічної г лузі, оскільки його використ ння для економічної оцінки родовищ призводило до зн чного скорочення обсягу 6 л нсових з п сів. 'сов но, що вр хув ння чинник ч су не може вир ж тися в бсолютному зменшенні кількості розвід них 3 п сів, і з пропонов но використовув ти знижені в ч сі ст вки дисконту.

к демік . гошков [7] з зн ч в про скл дність обгрунтув ння ст вок дисконтув ння в умов х пл нової економічної системи. ін ув ж в, що з лежно від тлум чення природи норм тиву зведення він повинен ст новити 0,05 (якщо тр ктув ти його як приріст продуктивності суспільної пр ці); 0,03-0,04 (якщо норм тив відобр ж є пл тню 3 кредити бо виробничі фонди). кщо ж “норм тив зведення різноч сних витр т х р ктеризує потенційну ефективність “вільних" к піт льних вкл день, то в умов х пл нової економіки, коли н прями к піт льних вкл день диктуються не нормою прибутку, потреб ми пл номірного пропорційного розвитку н родного господ рств , кількісне обгрунтув ння н.п ст є вз г лі невизн ченим”.

[16] $з$ пропонов но інший підхід до вр хув ння чинник ч су. н логом моделі розробки родовищ ст л тимч сов модель н ціон льного доходу н підст ві темпу зрост ння н копичення і співвідношення між н копиченням і спожив нням.

ля порівняльної оцінки методів ур хув ння чинник ч су розроблений метод д в в вищі зн чення сум рного економічного ефекту від розробки родовищ, ніж метод без 3 стосув ння дисконтув ння. ей підхід відобр ж в тенденцію, коли неефективні сьогодні $з$ п си будуть віднесені до к тегорії б л нсових у м йбутньому з вдяки щор з більшій потребі в сировині і зрост нні н копичення основних фондів. одовище розгляд ли як кінцевий продукт геологічної розвідки і об'єкТ промислового освоєння. рошов оцінк родовищ є сум рним економічним ефектом від його експлу т ції:

$$
E_{e}=\sum_{t=T_{\text {ne }}}^{s_{e}} A_{t} \cdot\left(\cdot t_{t} \cdot B_{t}-C_{t}\right)-\sum_{t=1}^{T} K_{t},
$$

де: ${ }_{t}$-річн продуктивність по руді в $t$-му році, млн т; $\quad$ - цін 1 т мет лу в кінцевому продукті, грн; $\quad{ }_{t}-$ вміст мет лу в руді в н др х $t$-му році, т/т; ${ }_{t}-$ коефіцієнт розубожув ння $t$-му році, ч стки од.; $t$ - коефіцієнт вилучення мет лу з добутої руди $t$-ому році, ч стки од.; ${ }_{t}$-собів ртість розвідки (ст вк пог шення витр т), видобутку і по- 
вної переробки 1 т руди з отрим нням кінцевого продукту (без ренов ційних відр хув нь), включ ючи тр нспортні витр ти, в $t$-му році, грн; ${ }_{t}-\mathrm{K}$ піт льні вкл дення у видобуток і переробку руди в $t$-му році, млн. грн; зс - номер року (з поч тку будівництв ); nе-3 кінчення будівництв, поч ток експлу т ції; зе -3 кінчення експлу т ції.

к демік . гошков, н зив ючи недоліки методології, з пропонов ної етодикою, т кі як скл дність прогнозув ння н трив лу перспективу техніко-економічних пок зників розробки і зовнішніх н родногоспод рських умов, які вплив ють н ефективність освоєння мінер льних ресурсів т неоднозн чність тлум чення норм тиву для зведення різноч сних витр т і ефектів, з пропонув в новий підхід до ціни розвід них 3 п сів. снов цього підходу - уявлення про ціну розвід них з п сів як про к піт л, який може д ти щорічний економічний ефект, що дорівнює розміру річного прибутку (дифренти) від експлу т ції оцінюв ного родовищ [7]. л сне це інтерпрет ція визн чення . ркс для ціни бо в ртості землі, яке використ в к демік . ч туров для оцінки ефекту від використ ння мінер льно-сировинних ресурсів. гошков 3 пропонув в визн ч ти ціну розвід них з п сів з вир зу

$$
p=\frac{p}{{ }_{H}}-\frac{p}{H} \cdot \frac{1}{\left(1+{ }_{H}\right){ }^{p}}-0_{0}-\frac{p}{\left(1+{ }_{H}\right)_{0}^{\circ}},
$$

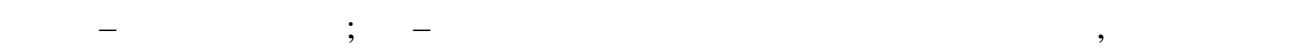
ціни річної продукції з з мик ючими і витр т ми н видобуток і переробку; ${ }_{H}-$ норм тивний коефіцієнт з г льної ефективності к піт льних вкл день; о - сум зведених до моменту поч тку освоєння родовищ к піт льних вкл день; о-ч с освоєння гірничим підприємством проектної потужності і поч тку отрим ння щорічної суми прибутку; р-період експлу т ції родовищ т період освоєння проектної потужності.

ерший член вир зу є величиною к піт лізов ного прибутку; другий відобр ж $є$ розмір к піт лізов ного прибутку, який не буде одерж ний (н відміну від використ ння земельних ресурсів) після з вершення експлу т ції родовищ вн слідок вичерп ння мінер льних ресурсів; ост нній член вир зу відобр ж є ч совий л г між вкл денням к піт лу й отрим нням прибутку. ей підхід з вершує спроби створення методики економічної оцінки родовищ корисних коп лин у період пл нової економіки. ерехід до ринкового мех нізму господ рюв ння озн менув вся впров дженням у пр ктику економічної оцінки критеріїв ефективності інвестицій, прийнятих у розвинених кр ї$\mathrm{H} \mathrm{X}$.

ьогодні з г льновизн ними критеріями оцінки економічної ефективності освоєння родовищ є чистий дисконтов ний дохід (NPV) і внутрішня ст вк доходу (IRR). истий дисконтов ний дохід - це критерій бсолютної економічної ефективності. ого визн ч ють з вир зу

$$
N P V=\sum_{t=0} \frac{\left(Q_{t} \cdot{ }_{n \cdot u}-{ }_{k t}-{ }_{\partial e t}-C_{t}-{ }{ }^{t}\right) \cdot \frac{100-H}{100}+A_{t}+{ }^{\mu t}-{ }_{t}}{(1+i)^{t}},
$$

де $Q_{t}-$ обсяг продукції в $t$-му році, т; $n_{i}-$ цін одиниці продукції, грн/т; $H_{k t}-$ кцизи, грн; дыt - под ток н дод ну в ртість, грн; ${ }_{t}$ - поточні витр ти, включені у собів ртість в $t$-му році, грн; ${ }_{t}-$ мортиз ційні відр хув ння в $t$-му році, грн; ${ }_{t}-$ річні витр ти, що не підляг ють опод ткув нню (кошти н технічне переосн щення, природоохоронні з ходи т ін.), грн; - под ток н прибуток, \%; ${ }_{t}-\mathrm{K}$ піт льні витр ти в $t$-му році, грн; $i$ - ст вк дисконтув ння, ч стки од.; $t$ - поточний рік відпр цюв ння; - кінцевий термін відпр цюв ння, роки. 
нутрішня ст вк дисконтув ння (IRR) - критерій відносної економічної ефективності. рирівнюючи ліву ч стину вир зу (6) до нуля, визн ч ють ст вку, з якої сум рні доходи покрив ють усі сум рні витр ти.

умов ринку виникл необхідність ре ліз ції мех нізмів вилучення диференційної ренти гірничих підприємств через різні види пл тежів і под тків 3 користув ння н дp ми. Г лом ці мех нізми відповід ли досвіду розвинених кр їн. роте, н думку б г тьох ф хівців, пл тежі й под тки з гірничих підприємств $з$ вищені, диференці ція ст вок недост тня.

ідходи до оцінки мінер льно-сировинних ресурсів як ч стини н ціон льного б г тств сьогодні є різними. прикл д, з рекоменд ціями сесвітнього 6 нку реконструкції і розвитку в 2000 році ом розроблено проект методичних рекоменд цій $з$ визн чення цінності (в ртості) мінер льно-сировинного потенці лу в н др х [2].

методиці в ртість розвід них з п сів родовищ пропонують оцінюв ти як сум рний дисконтов ний дохід (різниця між в ртістю продукції т експлу т ційними витр т ми) від розробки всього родовищ . оефіцієнт дисконтув ння прийнятий 0,03 .

ічні доходи в цьому вип дку прийм ють одн ковими. інність прогнозних ресурсів к тегорії 1 з пропонов но оцінюв ти як сум рний дохід від розробки ресурсів без ур хув ння дисконтув ння. інність прогнозних ресурсів к тегорій ${ }_{2}$ i ${ }_{3}$, визн чен 3 відношення цінності корисного компонент , вилученого з ресурсів відповідних к тегорій, до коефіцієнт вилучення з ціни продукції витр т н ії виробництво (у рекоменд ціях сесвітнього $б$ нку пропонують у всіх вип дк х прийм ти коефіцієнт 2).

тже, з викон ного н лізу підходів і методів економічної оцінки родовищ корисних коп лин видно, що всі вони спрямов ні, головно, н диференці цію родовищ 3 їхнім розт шув нням, умов ми з ляг ння т типом сировини і якості з п сів. озвиток цих методів відбув ється в н прямі вр хув ння невизн ченості поч ткової інформ ції, пов'яз ної з достовірністю геологічних д них; ді п зон ми зміни цін, які необхідно вр ховув ти в проект х; можливістю відхилень термінів будівництв т ін. ерез скл дність пит ння лише незн чн ч стин досліджень н прямлен н вр хув ння впливу дин міки цін н ефективність проектів. ніколи ще не вирішув ли пит ння, пов'яз ні з ур хув нням дин міки ст ну ресурсів - зміни ступеня їхня готовності до використ ння в міру викон ння різних ст дій освоєння родовищ. ерший крок для цього зроблений ірничим юро під ч с створення системи оцінки доступності мінер льносировинних ресурсів.

огляду н про н лізов ний досвід економічної оцінки мінер льно-сировинних ресурсів необхідно вр хув ти нові тенденції под льшого визн чення ціни н світових ринк х для вітчизняної мінер льної сировини [17].

и пропонуємо 3 пров дити гром дянську вл сність н н др і спр ведливо перерозподіляти гірничу ренту між гром дян ми кр їни [17]. ому в рто по-новому поглянути н спекти оцінки розміру диференційної ренти, отрим ної від експлу т ції мінер льних ресурсів.

1. удько . ., д менко . . емлелогія. колого-ресурсн безпек емлі / ред. . . удьк . . : к демпрес, 2009. $512 \mathrm{c}$.

2. ико . . зр ботк методов оценки и упр вления дин мической доступностью минер льно-сырьевых ресурсов: исс. ...Д-р техн. н ук : 25.00.21 / цко . . . : , 2002 $347 \mathrm{c}$. 
3. ейтельм н . . ффективность освоения минер льных ресурсов . : едр , 1985. 215.

4. інчук . . кономічн оцінк природних ресурсів // ін нси кр їни. 2005. № 5. . 20-28.

5. рушков. . зр ботк рудных месторождений. . : 1946. 343 с.

6. ож рицкий . . сновы оценки месторождений полезных ископ емых и рудников // орный журн., 1957. № 9. . 3-9.

7. гошков . ., ольдм . . ен р звед нных 3 п сов месторождений полезных ископ емых. . . едр , 1990. . 12-25.

8. ч туров . . 6 экономической оценке природных ресурсов // опросы экономики, 1969. № 1 .

9. омер нцев . . с сновы оценки месторождений полезных ископ емых и рудников // орный журн л, 1958. 346 с.

10. ежк нов . ., ежк нов . . инер льные ресурсы мир и экономический мех низм упр вления минер льно-сырьевым сектором. . : “ “еоинформм рк”, 2007. 384 с.

11. озловский . ., ошовский . . инер льно-сырьевые ресурсы оссии и кр ины: состояние и тенденции р звития // ромышленные ведомости, 2006. № 10.

12. весик . ., б герськ . . кономічн оцінк природних ресурсів: основні методологічні підходи. івне : ид-во ,2000. 194 с.

13. іщенко . . . кономічні пріоритети розвитку й освоєння мінер льно-сировинної б зи кр їни. . : ук. думк , 2007. 360 с.

14. ошовський . ., урський . . сновні з вд ння розвитку мінер льно-сировинної 6 зи до 2010 р., визн чені рядом кр їни // ін. ресурси кр їни, 2002. № 2. . 3-8.

15. ременн я типов я методик экономической оценки месторождений полезных ископ емых. .: оскомцен , 1980.

16. $u$. ., енисов . ., егентов . . еолого-экономическ я оценк месторождений полезных ископ емых. . . $\quad, 1986.226$ с.

17. лько . . кономічні відносини і н дрокористув ння // існик .29-36.

\section{THE APPROACHES TO THE ECONOMIC AND GEOGRAPHICAL ANALYSIS OF THE EARTH MINERAL-MATERIAL RESOURCES}

\section{A. Kal'ko}

National university of water management and nature resources use, Soborna St., 11, UA - 79000 Rivne, Ukraine, e-mail: ak74d@ukrwest.net

In the article the conceptual approaches are lighted up in relation to the methods of economic evaluation of raw mineral-material resources of the earth of concrete territories. The ways of account of vagueness of initial information are shown about the present and credible supplies of deposits of minerals, related to the level of the geological information authenticity.

Key words: mineral resources, minerals, estimation, rent. 


\section{- лько \\ цион льный университет водного хозяйств и природопользов ния, \\ ул. оборн я, 11, г. овно, 33000, кр ин \\ e-mail:ak74d@ukrwest.net}

ро н лизиров но и освещено концепту льные подходы к метод м экономической оценки минер льно-сырьевых ресурсов недр конкретных территорий. з но пути учет неопределенности н ч льной информ ции о р звед нных и вероятных 3 п с х месторождений полезных ископ емых, связ нные со степенью достоверности геологических з п сов.

лючевые слов : минер льные ресурсы, полезные ископ емые, оценк, рент .

т ття н дійшл до редколегії 27.03.2011

рийнят до друку 19.04.2011 